\title{
Quando éramos todos vivos: $e$ alguns poemas, de Maria Conceição Monteiro
}

\author{
Roberto Acízelo Quelha de Souza \\ UERJ, Brasil \\ https://orcid.org/0000-0003-0607-5911
}

or muito tempo, segundo tradições clássicas e depois românticas, a literatura se pautou por
certos valores estético-poéticos amplamente acatados, praticamente consensuais: o belo, o sublime, o gracioso, o verossímil, tudo isso instrumentalizado para tornar a leitura uma atividade ao mesmo tempo prazerosa e edificante. É verdade que alguns gêneros - a sátira, por exemplo, e, de certo modo, a tragédia - se definiam exatamente pela inversão desses valores, explorando o feio, o grotesco, o repugnante, o cruel. Tratava-se, assim, de dois decoros escrupulosamente separados, ao mesmo tempo que convergentes num efeito comum: quer pela via do belo, quer por meio de sua inversão simétrica, a literatura ou exaltava e reafirmava a beleza e seus atributos correlatos, ou, expondo a desolação de um mundo privado de tais predicados, induzia a necessidade de preservá-los ou restaurá-los.

Esse estado de coisas, essa ordem estável e fortemente racionalista, a modernidade se encarregou de reverter, como bem sabemos. O limite claro e não ultrapassável entre os gêneros por assim dizer apolíneos, por um lado, e dionisíacos, por outro, se desfez, dando lugar a experiências produtoras de formas literárias híbridas e impuras. Talvez se possa mesmo dizer que, depois do longo império cultural dos primeiros sobre os segundos, os gêneros dionisíacos se impuseram, e desde então desobrigados da antiga missão de, em última instância, contribuir para a hegemonia incontestável do apolíneo.

Escrever, assim, deixou de ser um compromisso com a promoção de valores tendentes ao consenso, para tornar-se ou um ato gratuito, de efeito indireto e remoto sobre o intelecto e a sensibilidade, ou um ato crítico por excelência, destinado a pôr em questão todos os conceitos e preconceitos, todas as crenças e convicções. Ler, correlativamente, distanciou-se de sua antiga condição de processo predominantemente passivo - uma interpretação mais ou menos segura de uma mensagem vazada em código aceito e familiar -, para assumir-se também como gesto 
ativo, dado que não pode mais dispor do apoio em convenções universais, chegando mesmo, no limite, ao confrontar-se com arranjos verbais inusitados e herméticos, a tangenciar o próprio escrever, à medida que o leitor se vê na contingência de inventar significações e sentidos, emulando assim o próprio escritor.

Quando éramos todos vivos e alguns poemas, de Maria Conceição Monteiro, é um livro cuja legibilidade depende em boa parte de se terem em conta as considerações acima desenvolvidas. Alinha-se decididamente no campo do livre experimentalismo literário, à medida em que se afasta das convenções que, não obstante a já velha virada moderna e modernista, continuam muito vigorosas entre amplos segmentos de leitores.

De saída, transpõe a fronteira entre os gêneros, pois a uma parte inicial em prosa narrativa segue-se um conjunto de poemas. A narrativa constrói um espaço e um tempo nebulosos e algo nonsense, bem como povoados de figuras de sentido enigmático, como o ser onírico referido na seguinte passagem:

A rata tinha dentes afiados, olhos de inverno triste. Era uma rata do frio que vivia num subsolo impiedoso. Melancólica, sentia dor, transbordava de dor e a dor ressoava como a voz numa casa sem móveis, nem objetos domésticos, nem quadros e nem retratos (MONTEIRO, 2019, p. 13).

Os poemas, por sua vez, de ritmos livres e "inumeráveis", ${ }^{1}$ também se caracterizam por criarem sentidos indefinidos, armando uma penumbra semântica que faculta aos leitores discernirem, na indeterminação das sentenças em versos, como que vultos de significados. Veja-se, por exemplo, a composição que tem por título "No oco do mundo": "Por trás da pedra / Não, por debaixo da pedra // Descida roliça / Rolando tantas voltas // Por trás daquela vida / Vivia um rio morno // Lá habitavam um tempo costurado / Nas pregas das vagas // Vivo aí, comigo" (MONTEIRO, 2019, p. 55). Ou esta outra, "Sentir": "Me perguntas sobre o amor ${ }^{2} / /$ O infinito imponderável / Sentimento oculto ${ }^{3}$ / Enrubesce o tempo // Ultrapassa o limite / dos horizontes / Perde-se / Pois não há // Existência ausente / Uma ideia apenas / É o que resta” (p. 58).

Assim, a narrativa e os poemas exigem do leitor uma recepção aberta a inovações temáticas e formais, praticamente cobrando sua participação na construção das significações, a partir de fragmentos sintáticos, dissonâncias, enunciados paradoxais, jogos intertextuais ${ }^{4}$ e exercícios metapoéticos. O poema "Metamorfose", aliás, constitui a chave dessa construção difícil e refratária à compreensão rasa e imediata: "Sem ordem / Fronteira / Conexões // Vestiu-se de cacos / Caótica // Sem forma / Contorno / Fins // Abriu as asas / Subiu o pico / Tocou o infinito / Desabou" (MONTEIRO, 2019, p. 52). No entanto, como mesmo as subjetividades propensas a discursos transgressores de sintaxe e semântica revelam-se também capazes de manifestações verbais estruturadas, Quando éramos todos vivos não deixa de ter os seus momentos de clareza

\footnotetext{
Cf.: "Todos os ritmos sobretudo os inumeráveis" ("Poética", de Manuel Bandeira).

2 Cf.: "Falas de amor, e eu ouço tudo e calo!" ("Versos de amor", Augusto dos Anjos).

${ }^{3}$ Cf.: "Ninguém te viu o sentimento inquieto, / magoado, oculto e aterrador, secreto, / que o coração te apunhalou no mundo" ("Vida obscura”, Cruz e Sousa).

${ }^{4}$ Ver as remissões literárias que fizemos nas notas 2 e 3, talvez algo arbitrárias, mas também o que se evidencia no título de certos poemas, remissivos a filmes e a uma canção: "Luzes da cidade", "Um corpo que cai", "Imitação da vida", "Força estranha".
} 
e aptos à facilidade de leitura (cedem as asperezas à suavidade), o que configura mais um dos traços do seu caráter híbrido. É o que se vê, entre outras passagens, nos períodos finais da narrativa, e em poemas como "Lágrimas": "As labaredas, que ardiam desde o tempo das cirandas em volta do fogo, no quintal da casa da esquina, consumiram fotografia a fotografia, e assim todas as histórias e os sonhos de quando éramos todos vivos reverteram em cinzas que o vento logo espalhou" (MONTEIRO, 2019, p. 48); "Pousas na minha vidraça / Escorres espelho abaixo / Te toco / Escapas // Ressurges / Mais uma vez deslizas // Te imagino / Tocando o dedo / No teu percurso // Fria em meio de cores / Rompes / Corrompes / Desmanchas // Refletes a minha alma / Contigo desabo / Em mil gotinhas" (MONTEIRO, 2019, p. 57).

\section{REFERÊNCIA}

MONTEIRO, Maria Conceição. Quando éramos todos vivos: e alguns poemas. Rio de Janeiro: Caetés, 2019. 